\title{
ハロゲン化物イオンの陰イオン交換樹脂への吸着におよぼす 磁場の影響
}

\author{
（1991 年 5 月 28 日受 理）
}

千葉 淳* 巻口啓人・田村寿康** 佐藤栄 一**

ハロゲン化物イオンの陰イオン交換樹脂 Dowex 2-X 8 ヘの吸着において，総イオン交換量は同じで あった。フッ化物および塩化物イオンは外部磁場の印加によって飽和吸着量に達するまでの時間が約半 分になり, 吸着開始後 10 分後の交换速度が $20 \%$ 大きくなった。臭化物拉よびョウ化物イオンは吸着 開始後 3 時間後の交換速度は 10〜20\% 大きくなった。八ロゲン化物イオンのイオン交換反応の律速段 階は膜内拡散および粒子内拡散に支配されていた。拡散係数および速度定数はいずれのハロゲン化物イ オンも磁場の印加によって大きくなった。

\section{1 緒 言}

著者らの一人は既報でキレート樹脂 Dowex A-1への金属イオ ンの吸着で, 外部磁場の印加が金属イオンの吸着量と吸着率を向 上させることを報告し1)，イオン交換反応の律速段階の解析を行 った2)。イオン交換の過程は 1) 樹脂表面への溶液を通してのイ オンの拡散，2）樹脂内に拈けるイオンの拡散，3）樹脂中の可動 性イオンとの交換，4）樹脂を通じての交換したイオンの拡散,

5）交換したイオンの溶液中への拡散の五つの段階で進行してい る。このイオン交換の過程からイオン交換反応の律速段階は膜内 拡散と粒子内拡散と考兄られている。

本研究は, 強塩基性陰イオン交換樹脂 Dowex 2-X 8 を用い, バッチ法で八ロゲン化物イオンを吸着させ, 磁場の交換速度にお 上ぼす影響を検討するとともに，磁場がイオン交換反応の律速段 階に影響することを明らかにすることを目的とした。

\section{2 実験}

\section{1 試薬および樹脂}

八ロゲン化物イオン標準溶液 : ナトリウム塩を蒸留水に溶解さ せ $0.3063 \mathrm{mgF}^{-} \cdot \mathrm{cm}^{-3}, \quad 0.2500 \mathrm{mg} \mathrm{Cl} \mathrm{Cl}^{-} \cdot 2.450 \mathrm{mg} \mathrm{Br}{ }^{-}$. $\mathrm{cm}^{-3}, 3.820 \mathrm{I}^{-} \mathrm{mg} \cdot \mathrm{cm}^{-3}$ の溶液を使用した。

イオン交換樹脂: $500 \mathrm{~cm}^{3}$ の陰イオン交換樹脂 Dowex 2-X 8 (ダウケミカル社, 室町化学工業株式会社肘売, 総交換量 1.4 $\mathrm{meq} \cdot \mathrm{cm}^{-3}$ (湿㵎樹脂) 100〜200 メッシュ) 3) をカラムにつめ, $1 \mathrm{~mol} \cdot \mathrm{dm}^{-3}$ 水酸化ナトリウム溶液 $500 \mathrm{~cm}^{3}$ を流し，つぎに蒸留 水で洗浄し, $\mathrm{OH}^{-}$形とした。 $45^{\circ} \mathrm{C}$ の空気浴で乾燥し, 実跧に供 した。用いた樹脂の含有水分量は $13 \%$ (乾量基準) であった。

横浜国立大学工学部 240 横浜市保土ケ谷区常盤台 156

** 宇都宮大学工学部 321 宇都宮市石井町 2753

1) 千葉 淳, 市石知史, 神田博克, 小川忠颜, 日化, 1987, 243.

2）千葉 淳, 神田博克, 小川忠彦，日化，1989，1677.

3）室町化学工業(株)カタログ（1985）.

\section{2 操作}

一定濃度のハロゲン化物イオン溶液 $100 \mathrm{~cm}^{3}$ をイオン交換樹 脂 $1.00 \mathrm{~g}$ の入った共栓三角フラスコに加兄, $25^{\circ} \mathrm{C}$ で吸着平衡に 達するまで吸着させた。吸着量は, 一定時間経過後, 溶液から一 定量採取して非吸着量を求め, 仕达量との差から求めた。塩化 物, 臭化物拉よびョウ化物イオン濃度は硝酸銀溶夜による電位差 滴定で測定した。また，フッ化物イオン濃度はキレート滴定法で 測定した。イオン交換反応の律速段階の解析は既報と同じ方法” で行った。磁場の印加は，サマリウムコバルト永久磁石 $(36 \mathrm{~mm}$ $\times 36 \mathrm{~mm} \times 25 \mathrm{~mm}$ ) のN極を上にしてフラスコの底に置いて得た。 磁場の強さは樹脂層の位置で $0.25 \mathrm{~T}$ であった。

\section{3 結果および考察}

\section{1 樹脂, 総イオン交換容量, 溶液の粘度および導電率}

磁場の印加によって樹脂の膨潤珄は变化せず，樹脂の構造は磁 場の影響を受けないとした。総イオン交换容量の大きさは， $\mathrm{I}^{-}>$ $\mathrm{Br}^{-}>\mathrm{Cl}^{-}>\mathrm{F}^{-}$イオンの順であり, 磁場印加の影響は認められな かった。ハロゲン化物イオン溶液の粘度と導䉓率も影響が認めら れず，いずれる本条件下では無視した。

\section{2 フッ化物イオン}

吸着におよぼす時間の影響を図 1 に示した。磁場を印加した場 合, 吸着開始後約 35 分後に平衡 (吸着量 $13.5 \mathrm{mg} / \mathrm{g}$-樹脂) に達 した。無磁場の場合は, 約 1 時間後に平衡に達した。磁場印加の 場合，平衡に達するまでの時間は，哭磁場と比較して約 $50 \%$ 短 くなった。交換速度は吸着直後から時間とともに大きくなり、10 分間で最大となり，無磁場の場合と比較して約 $20 \%$ 增加した。

$-\log (1-F)$ を時間 $t$ 亿，反応度 $F$ を $t^{1 / 2}$ におよび $\log Z$ を時 間 $t$ に対してプロットしたものをそれぞれ図 $2 ３ ３$ および 4 に示 した。いずれの関係も，磁場を印加した場合および無磁場の場合 とも直線関係が得られた。したがって、フッ化物イオンのイオン 交換反応の律速段階は膜内拡散拉よび粒子内拡散に支配されてい ると考えた。また，磁場を印加した場合は，無磁場の場合にくら べて直線の傾きがすべて大きくなり，払散係数怙よび速度定数は 


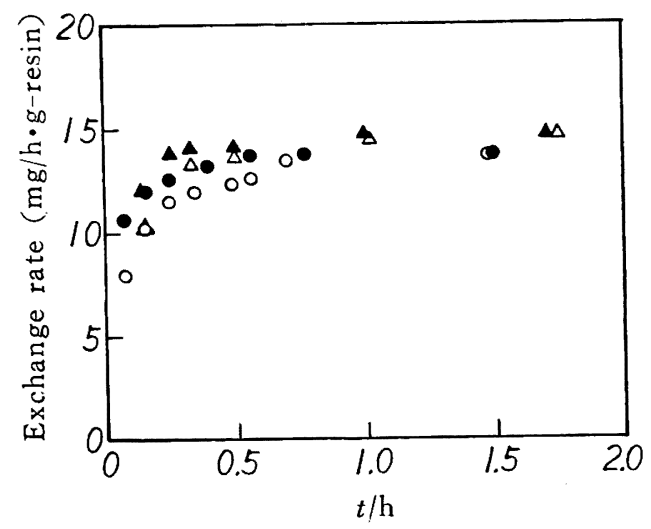

Fig. 1 Plot of the exchange rate of fluoride and chloride ions versus time

Initial concentration : $(\bigcirc, \bigcirc) 0.3063 \mathrm{mgF}^{-} / \mathrm{cm}^{3}$,

$(\triangle, \Delta) 0.2500 \mathrm{mgCl}^{-} / \mathrm{cm}^{3}, 100 \mathrm{~cm}^{3}$

Dowex 2 X $8: 1.00 \mathrm{~g}$

Magnetic flux density : $(O, \triangle) 0 \mathrm{~T},(\boldsymbol{\Delta}, \boldsymbol{\Delta}) 0.25 \mathrm{~T}$

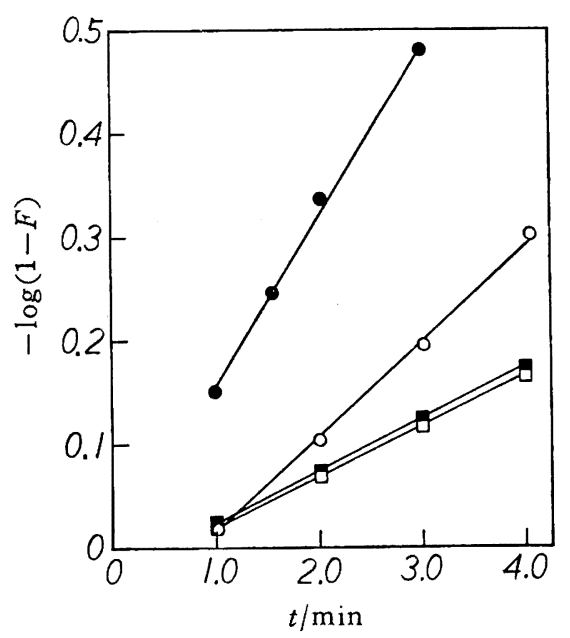

Fig. 2 Effect of magnetic field on the film diffusion of fluoride and bromide ions

Initial concentration : $(\bigcirc, \odot) 0.3063 \mathrm{mgF}^{-} / \mathrm{cm}^{3}$,

( $\square$, $2.450 \mathrm{mgBr}^{-} / \mathrm{cm}^{3}, 100 \mathrm{~cm}^{3}$

Dowex 2 X $8: 1.00 \mathrm{~g}$

Magnetic flux density: $(\bigcirc, \square) 0 \mathrm{~T}$, $0.25 \mathrm{~T}$

Table 1 Diffusion coefficient and rate constant

\begin{tabular}{lrccll} 
& & $\mathrm{F}^{-}$ & $\mathrm{Cl}^{-}$ & $\mathrm{Br}^{-}$ & \multicolumn{1}{c}{$\mathrm{I}^{-}$} \\
\hline $\begin{array}{l}\text { Susceptibility } \\
\times 10^{-6} \mathrm{~cm}^{3} \cdot \mathrm{mol}^{-1}\end{array}$ & & 11 & 26 & 36 & 52 \\
$\begin{array}{l}\text { Diffusion coefficien t } \\
\times 10^{-11} \mathrm{~m}^{2} \cdot \mathrm{min}^{-2}\end{array}$ & $0.25 \mathrm{~T}$ & 7.42 & 3.04 & 1.41 & 1.69 \\
Rate constant & $0 \mathrm{~T}$ & 0.125 & 0.013 & 0.035 & 0.0069 \\
min $^{-1}$ & $0.25 \mathrm{~T}$ & 0.280 & 0.017 & 0.40 & 0.074
\end{tabular}

大きくなった。樹脂の官能基の量が総イオン交換量と一致し，平 衡時におけるイオン交换容量も磁場の影響を受けなかったと仮定 ᄂ, 抬散係数を求めると, 無磁場の場合 $7.42 \times 10^{-11} \mathrm{~m}^{2} \cdot \mathrm{min}^{-1}$, 磁場印加の場合 $24.0 \times 10^{-11} \mathrm{~m}^{2} \cdot \mathrm{min}^{-1}$ となり，拡散係数は磁 場の影響で約 3 倍增加した。また，速度定数は無磁場の場合，

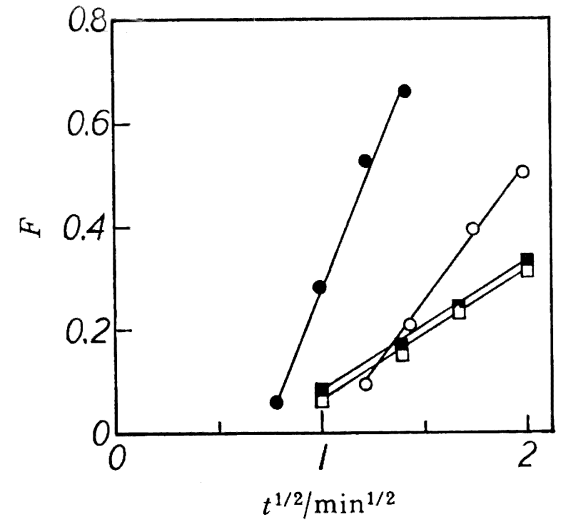

Fig. 3 Effect of magnetic field on the particle diffusion of fluoride and bromide ions

Initial concentration : $(\mathrm{O}, 0) 0.3063 \mathrm{mgF}^{-} / \mathrm{cm}^{3}$,

( $\square$, $2.450 \mathrm{mgBr}^{-} / \mathrm{cm}^{3}, 100 \mathrm{~cm}^{3}$

Dowex $2 \times 8: 1.00 \mathrm{~g}$

Magnetic flux density: $(\bigcirc, \square) 0 \mathrm{~T},(\boldsymbol{O}, \boldsymbol{\square}) 0.25 \mathrm{~T}$

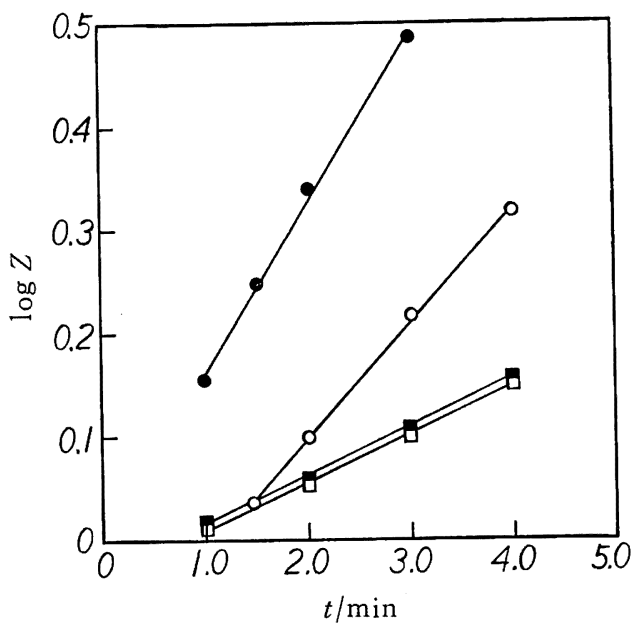

Fig. 4 Effect of magnetic field on the ion-exchange reaction of fluoride and bromide ions

Initial concentration : $(\bigcirc, \bigcirc) 0.3063 \mathrm{mgF}^{-} / \mathrm{cm}^{3}$,

( $\square$, $2.450 \mathrm{mgBr}^{-} / \mathrm{cm}^{3}, 100 \mathrm{~cm}^{3}$

Dowex 2 X $8: 1.00 \mathrm{~g}$

Magnetic flux density: $(O, \square) 0 \mathrm{~T}$,

$0.25 \mathrm{~T}$

$0.125 \mathrm{~min}^{-1}$, 磁場印加の場合 $0.280 \mathrm{~min}^{-1}$ となり, 磁場の影響で 約 2.2 倍增加した。他のハロゲン化物イオンの抎散係数と速度定 数とともに表 1 に示した。

\section{3 塩化物イオン}

交換速度におよぼす時間の影響を図 1 に示した。磁場を印加し た場合，吸着開始後約 50 分後に平衡（吸着量 $14.5 \mathrm{mg} / \mathrm{g}$-樹脂） に達した。傿磁場の場合は, 約 90 分後に平衡に達した。磁場印 加の場合, 鴒和吸着量に達するまでの時間は, フッ化物イオンと 同椂, 約 $50 \%$ 短くなった。交换速度は吸着直後から時間ととも に大きくなり 10 分間で最大となり，無磁場の場合と比較して約 $20 \%$ 归加した。

$-\log (1-F)$ を時間 $t$ に，反応度 $F$ を $t^{1 / 2}$ におよび $\log Z$ を時 閒 $t$ に刘してプロットしたものをそれぞれ図 5,6 および 7 に示 した。いずれの関係も, 磁場を印加した場合および無磁場の場合 


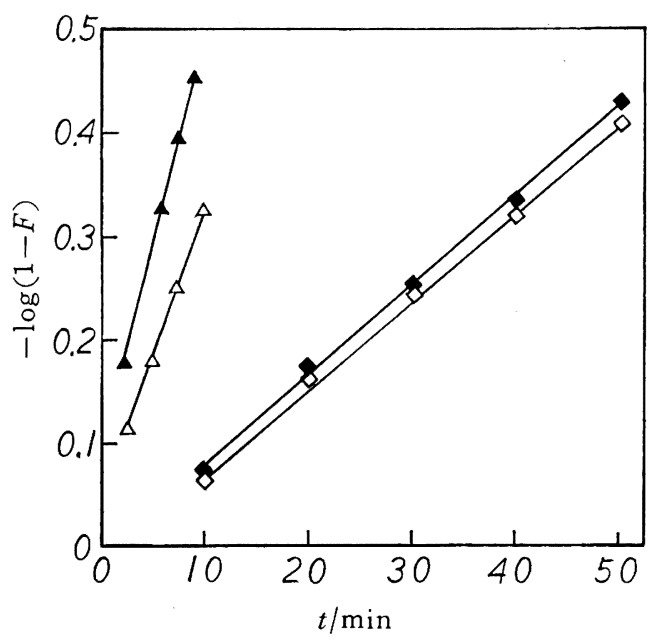

Fig. 5 Effect of magnetic field on the film diffusion of chloride and iodide ions

Initial concentration : $(\triangle, \Delta) 0.250 \mathrm{mg} \mathrm{Cl}^{-} / \mathrm{cm}^{3}$,

$(\diamond, \diamond) 3.820 \mathrm{mgI}^{-} / \mathrm{cm}^{3}, 100 \mathrm{~cm}^{3}$

Dowex 2X $8: 1.00 \mathrm{~g}$

Magnetic flux density: $(\triangle, \diamond) 0 \mathrm{~T},(\mathbf{\Delta}, \boldsymbol{\diamond}) 0.25 \mathrm{~T}$

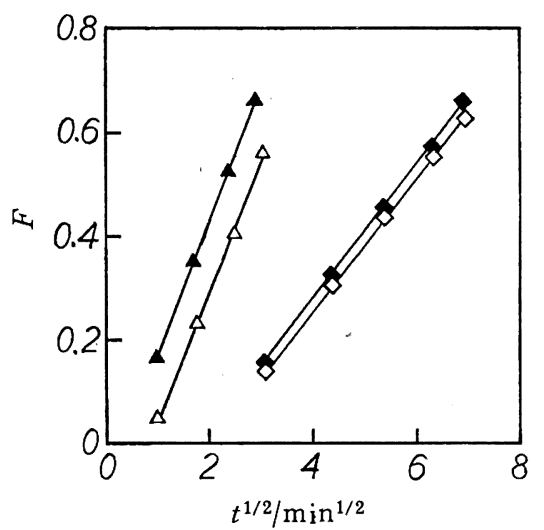

Fig. 6 Effect of magnetic field on the particle diffusion of chloride and iodide ions

Initial concentration : $(\triangle, \Delta) 0.250 \mathrm{mgCl}^{-} / \mathrm{cm}^{3}$,

$(\diamond, \diamond) 3.820 \mathrm{mgI}^{-} / \mathrm{cm}^{3}, 100 \mathrm{~cm}^{3}$

Dowex 2 X $8: 1.00 \mathrm{~g}$

Magnetic flux density : $(\triangle, \diamond) 0 \mathrm{~T},(\mathbf{\Delta}, \diamond) 0.25 \mathrm{~T}$

とも直線関係が得られた。したがって，塩化物イオンのイオン交 換反応の律速段階は膜内拡散扣よび粒子内拡散に支配されている と考えた。また，磁場印加の場合は無磁場の場合にくらべて直線 の傾きがすべて大きくなり，拡散係数括よび速度定数は大きくな った。そこで, フッ化物イオンと同様に，拡散係数を求めた。無 磁場の場合 $3.04 \times 10^{-11} \mathrm{~m}^{2} \cdot \mathrm{min}^{-1}$, 磁場印加の場合 $3.46 \times 10^{-11}$ $\mathrm{m}^{2} \cdot \mathrm{min}^{-1}$ となり，磁場の影響で約 $14 \%$ 增加した。また，速 度定数は, 無磁場の場合 $0.013 \mathrm{~min}^{-1}$, 磁場印加の場合 0.017 $\min ^{-1}$ となり，磁場の影響で約 $30 \%$ 增加した。

\section{4 臭化物イオン}

交換速度に括よぼす時間の影響を図 8 に示した。磁場を印加し た場合と無磁場の場合とも，吸着開始後約 5 時間後に平衡（吸着 量 $160.3 \mathrm{mg} / \mathrm{g}$-樹脂）に達し, 平衡に達するまでの時間に差は認

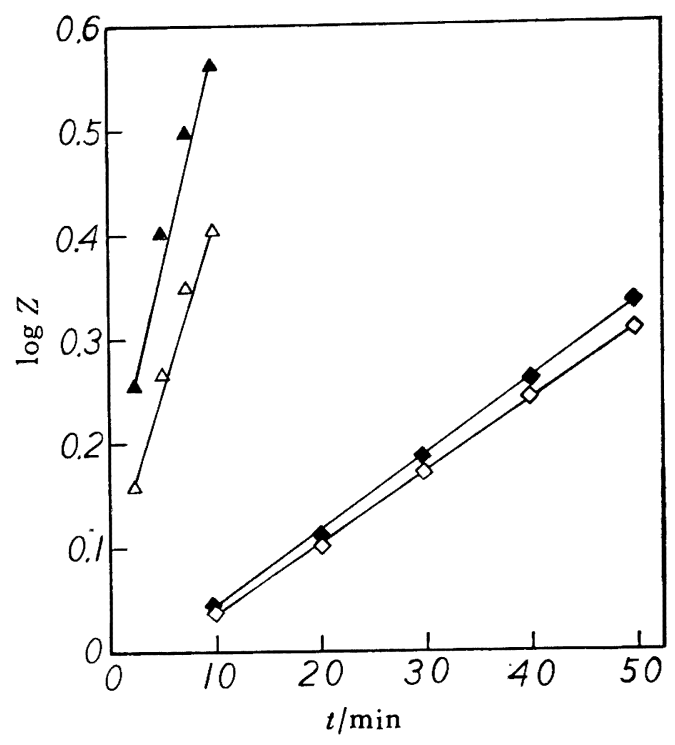

Fig. 7 Effect of magnetic field on the ion-exchange reaction of chloride and iodide ions

Initial concentration : $(\triangle, \triangle) 0.250 \mathrm{mgCl}^{-} / \mathrm{cm}^{3}$, $(\diamond, \diamond) 3.820 \mathrm{mgI}^{-} / \mathrm{cm}^{3}, 100 \mathrm{~cm}^{3}$

Dowex 2 X $8: 1.00 \mathrm{~g}$

Magnetic flux density : $(\triangle, \diamond) 0 \mathrm{~T},(\Delta, \diamond) 0.25 \mathrm{~T}$

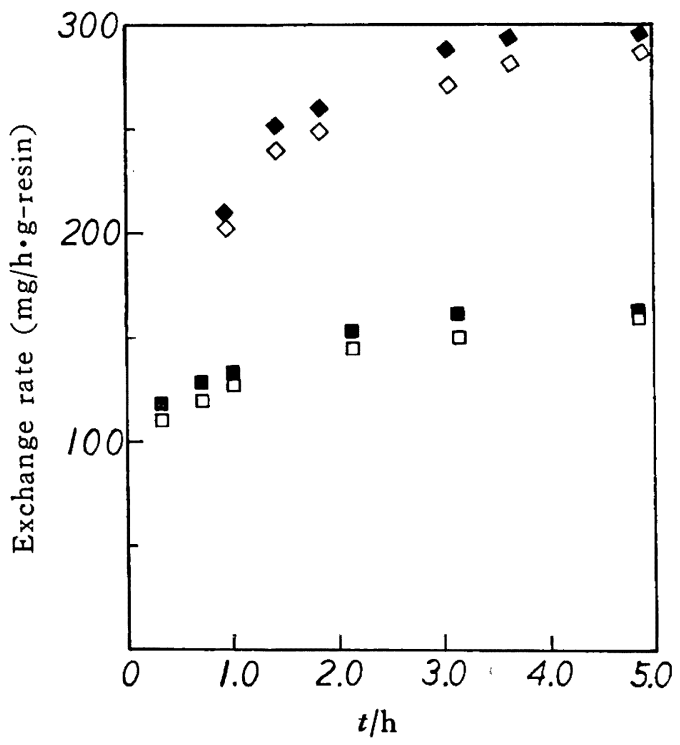

Fig. 8 Plot of the exchange rate of bromide and iodide ions versus time

Initial concentration : $(\square, \square) 2.450 \mathrm{mg} \mathrm{Br}^{-} / \mathrm{cm}^{3}$, $(\diamond, \diamond) 3.820 \mathrm{mgI}^{-} / \mathrm{cm}^{3}, 100 \mathrm{~cm}^{3}$

Dowex 2 X $8: 1.00 \mathrm{~g}$

Magnetic flux density: $(\square, \diamond) 0 \mathrm{~T}$, $0.25 \mathrm{~T}$

められなかった。しかし，磁場を印加した場合は無磁場の場合と 比較して, 約 1 時間から約 4 時間までの範囲で，交換速度に差が 認められ，約 3 時間で約 $20 \%$ 增加した。

$-\log (1-F)$ を時間 $t$ に，反応度 $F$ を $t^{1 / 2}$ におよび $\log Z$ を時 間 $t$ に対してプロットしたものをそれぞれ図 $2 ， 3$ および 4 に示 した。いずれの関係も，磁場印加の場合および無磁場の場合とも 直線関係が得られた。したがって，臭化物イオンのイオン交換速 
度の律速段階は膜内拡散および粒子内拡散に支配されていると考 えた。磁場を印加した場合は無磁場の場合にくらべて直線の傾き がすべて大きくなり，拡散係数および速度定数は大きくなった。 払散係数を求めると, 無磁場の場合 $1.41 \times 10^{-11} \mathrm{~m}^{2} \cdot \mathrm{min}^{-1}$, 磁場 印加の場合 $1.78 \times 10^{-11} \mathrm{~m}^{2} \cdot \mathrm{min}^{-1}$ となり，磁場の影響で約 $26 \%$ 増加した。また，速度定数を求めると，無磁場の場合 0.035 $\mathrm{min}^{-1}$, 磁場印加の場合 $0.040 \mathrm{~min}^{-1}$ となり，磁場の影響で約 $14 \%$ 增加した。

\section{$3.5 \exists ウ$ 化物イオン}

交換速度におよぼす時間の影響を図 8 に示した。磁場を印加し た場合と無磁場の場合とも, 吸着開始後約 10 時間後に平衡（吸 着量 $304.6 \mathrm{mg} / \mathrm{g}$-樹脂）に達し, 平衡に達するまでの時間に差は 認められなかった。しかし，約 2 時間から約 5 時間までは，交換 速度に差が認められ，約 3 時間で約 $10 \%$ 増加した。

$-\log (1-F)$ を時間 $t$ に, 反応度 $F$ を $t^{1 / 2}$ におよび $\log Z$ を時 間 $t$ に対してプロットしたものをそれぞれ図 5，6および 7 に示 した。いずれの関係も, 磁場を印加した場合および無磁場の場合 とも直線関係が得られた。したがって、ヨウ化物イオンのイオン 交換反応の律速段階は膜内拡散扣よび粒子内払散に支配されてい ると考えた。磁場を印加した場合は無磁場の場合にくらべて直線 の傾きが大きくなり，拡散係数および速度定数は大きくなった。 払散係数を求めると, 無磁場の場合 $1.69 \times 10^{-11} \mathrm{~m}^{2} \cdot \mathrm{min}^{-1}$, 磁場 印加の場合 $1.72 \times 10^{-11} \mathrm{~m}^{2} \cdot \mathrm{min}^{-1}$ となり，約 $2 \%$ 増加したが, 拡散係数におよぼす磁場の影響はほとんどないと考えられる。ま
た，速度定数を求めると，無磁場の場合 $0.0069 \mathrm{~min}^{-1}$, 磁場印加 の場合 $0.0074 \mathrm{~min}^{-1}$ となり，磁場の影響で約 $7.5 \%$ 增加した。

以上の結果, フッ化物, 塩化物, 臭化物およびョウ化物イオン の飽和吸着量は, 13.5, 14.5, 160.3 および $304.6 \mathrm{mg} / \mathrm{g}$-樹脂で あった。これらのイオン半径は，それぞれ $1.36,1.81,1.96$ 打 よび $2.20 \AA$ であり, イオン半径が大きく, 質量も大きいイオン は，飽和吸着量に達するまでの吸着洔間が長くなる傾向がみられ た。外部磁場を印加した場合，この吸着時間は短くなり，フッ化 物および塩化物イオンは, 約半分になった。速度定数の増加率も イオン半径の増加にしたがい減少していた。この要因の一つとし てハロゲン化物イオンと樹脂の衝突頻度を検討したが，変化は認 められず，関係ないと考えられた。また，八ロゲン化物イオンの 磁化率とイオン交換の定量的な関係も得られなかった。

\section{4 結 言}

1）磁場の影響を受け，イオン交換選択性の順序が変わうこと はなかった。

2）八ロゲン化物イオンと Dowex 2-X 8 のイオン交換反応の 律速段階は，膜内拡散拈よび粒子内拡散に支配されていると考兄 られた。しかしこれらの割合は不明であった。

3）フッ化物，塩化物，臭化物捄よびョウ化物イオンの拡散係 数および速度定数は，磁場を印加するとすべて増加した。その結 果，吸着開始後の交換速度は 10２0\% 大きくなった。

\title{
Magnetic Field Effects on the Adsorption of Halogen lons onto the Anion lon-exchange Resin
}

\author{
Atsushi $\mathrm{Chiba}^{*}$, Hiroto Makiguchi, Toshiyasu Tamura** and Eiichi Sato** \\ Faculty of Engineering, Yokohama National University ; 156, Tokiwadai, Hodogaya-ku, \\ Yokohama-shi 240 Japan \\ ** Faculty of Engineering, Utsunomiya University ; 2753, Ishiimachi, \\ Utsunomiya-shi 321 Japan
}

\begin{abstract}
Adsorption of halogen ions onto the anion ion-exchange resin, Dowex 2-X 8 , and ratedetermining steps of the ion exchange reaction were studied by means of the batch method in the presence of magnetic field. Halogen ions used were $\mathrm{F}^{-}, \mathrm{Cl}^{-}, \mathrm{Br}^{-}$and $\mathrm{I}^{-}$ions. The magnetic flux density was $0.25 \mathrm{~T}$. Ion-exchange rates of all ions were increased by about $10 \sim 20 \%$ by the presence of the magnetic field. Magnetic field does not affect on the degree of swelling, the structure of the resin, viscosities and electric conductivities of sample solutions, and total ion exchange capacities. It was found that the rate-determining step of all ionexchanges is the film diffusion and particle diffusion. Its diffusion coefficients and rate constants are increased by the pressence of the magnetic field.
\end{abstract}

